UDC 81

DOI: $10.24044 / \mathrm{sph} .2017 .4 .33$

\title{
SEMANTIC ANALYSIS OF STIMULUS-WORDS OF THE CONCEPT "CULTURE" IN THE LANGUAGE CONSCIOUSNESS OF YAKUT LANGUAGE SPEAKERS (on the example of the stimulus-word "folklore")
}

\author{
M. I. Kysylbaikova
}

\author{
Senior lecturer, ORCID 0000-0003-2082-3883, \\ e-mail: kysylbaikova@mail.ru, \\ North-Eastern Federal University \\ named after M. K. Ammosov, Yakutsk, \\ The Republic of Sakha (Yakutia), Russia
}

\begin{abstract}
This article is devoted to the semantic analysis of stimulus words of the concept "Culture" in the language consciousness of Yakut language seakers. There are 15 stimulus words, which were revealed as a result of the analysis of 25 Russian and 25 English definitions of the word "culture". The associative experiment is the basic method to get the world image of language speakers. Analysis of one word-stimulus (Folklore) is presented in this article. Comments on the received reactions to this word-stimulus are of interesting material, revealing the content and meaning of the stimulus-word. The most frequent reaction to word-stimulus 'folklore' is olonkho. Olonkho is a key moment in the folklore of the Sakha people.
\end{abstract}

Keywords: concept; culture; folklore; stimulus-word; olonkho.

According to the results of the etymological analysis and analysis of the dictionary entries of the word "culture", there were selected the following stimulus-words of the concept "Culture": culture, tradition, civilization, language, science, history, folklore, literature, art, religion, education, sport, spirituality, humanism, upbringing.

Using these stimulus-words a free associative experiment was held out among the Yakut language speakers with the purpose of representing the structure and content of the studied concept.

We agree with the opinion of Militsyna E. A., who asserts that the associative experiment allows us to reveal both the systemic content of the image of consciousness behind the word in different cultures and the systemic nature of the entire linguistic consciousness of the carriers of different cultures, thereby transferring the uniqueness and uniqueness of the image of the world of each culture. Language consciousness can be considered as a means of knowing another's culture in its subject, activity and mental forms and also as a means of knowing its culture [1].

In this article let us consider the analysis of the word-stimulus folklore in the language consciousness of the Yakut language speakers.

Frequent reactions of Yakut language speakers to word-stimulus folklore:

\begin{tabular}{|l|l|}
\hline \multicolumn{1}{|c|}{ Reactions } & \multicolumn{1}{c|}{ Quantity } \\
\hline olonkho (Yakut epic) & $27,5 \%$ \\
\hline folklore & $10 \%$ \\
\hline toyuk & $10 \%$ \\
\hline khomus & $8 \%$ \\
\hline osuokhai & $8 \%$ \\
\hline fairy-tale & $5 \%$ \\
\hline proverbs & $5 \%$ \\
\hline sayings & $2 \%$ \\
\hline
\end{tabular}




\begin{tabular}{|l|l|}
\hline song & $1,5 \%$ \\
\hline folk songs & $1,25 \%$ \\
\hline tongue twisters & $1,25 \%$ \\
\hline culture & $1 \%$ \\
\hline
\end{tabular}

Prosodic reactions:

\begin{tabular}{|l|l|}
\hline \multicolumn{1}{|c|}{ Reactions } & Quantity \\
\hline Yakut song with a measured melody & $0,5 \%$ \\
\hline high, solemn singing & $0,5 \%$ \\
\hline Yakut stories & $0,5 \%$ \\
\hline abaasy (evil spirit) & $0,4 \%$ \\
\hline Gavril Kolesov & $0,4 \%$ \\
\hline Ksenofontov G.V. & $0,35 \%$ \\
\hline Fedorova R.I. & $0,35 \%$ \\
\hline $\begin{array}{l}\text { Institute for Humanitarian Studies and Problems of Small } \\
\text { Peoples of the North }\end{array}$ & $0,3 \%$ \\
\hline habylyk / game consisting of tossing and picking up sticks & $0,25 \%$ \\
\hline
\end{tabular}

Total $84.05 \%$ responses, $15.95 \%$ refusals (319 refusals).

Proceeding from the received reactions it should be noted that the Yakut people throughout their history created a variety of folklore products: olonkho, folklore, toyuk, khomus, osuohai, fairy tale, proverb, sayings, song, folk songs, tongue twisters, culture, Yakut tales, which represent an oral chronicle of its development.

Yakut musical and poetic folklore is diverse. The central place in it is occupied by the monumental epic tales of olonkho. There are two types of singing: high, solemn singing and usual singing (Yakut song with a measured melody). The ancient epos olonk$h o$, passed from generation to generation by storytellers, is included in the list of UNESCO's World Intangible Heritage.

Yakut language speakers also mentioned Abaasy (evil spirit) as a reaction to the wordstimulus folklore. Mostly an abaasy is more related to Yakut mythology, nevertheless it was connected with the folklore. Abaasy an iron monster in the Yakut folklore, lives in the woods far away from human eyes.

Among the answers of the Yakut respondents it is possible to notice the names and names of people whose merits in the culture of Yakutia are invaluable. For example, Gavril Kolesov is a prose writer, Honored Artist of the YaSSR, RSFSR, People's Artist of the YaSSR, laureate of the State Prize of the Republic of Sakha Yakutia named after P. A. Oyunskiy. In 1961 his gramophone record on the olonkho by S. Vasiliev "Erchimen Bergen" was published in Moscow, in 1968 he recorded gramophone record on the olonkho "Nyurgun Bootur the Swift" by P. A. Oyunskiy, according to the latest olonkho many people know him as a talented artist. Ksenofontov G. $V$. - researcher of the history, ethnography and folklore of Yakut people, Fedorov R. I. - researcher, teacher of Yakut folklore, etc.

Some respondents associate folklore with the Institute for Humanitarian Studies and Problems of Indigenous Peoples of the North. As a result of purposeful gathering activity of several generations of researchers of this institute an invaluable fund of folklore creativity of Yakutia was created.

Khabylyk is a Yakut table game, consisting of tossing and picking up sticks, part of Yakut folklore.

It can be concluded that the Yakut culture is based on folklore, folklore is oral folk art. The folklore of Sakha people is rich and diverse. Among its various genres the prominent place belongs to the heroic epos olonkho. The reaction olonkho is in the first place among the reactions to the word-stimulus 
folklore. Olonkho is an epic poem about the heroic deeds of the ancient heroes. It arose in ancient times. The events described in it took place in immemorial antiquity, long before the appearance of a man-sakha in the Middle World. Olonkho for Sakha people is an encyclopedia of wisdom, art and poetry.

\section{Bibliography}

1. Militsyna E. A. Methods of researching the language consciousness [electronic resource]. URL: http://rudocs.exdat.com/docs/index493259.html?page $=13$

(C) Kysylbaikova M. I., 2017. 